\title{
Fasting lipids and anticardiolipin antibodies as risk factors for vascular disease in systemic lupus erythematosus
}

\author{
A J MacGregor, V B Dhillon, A Binder, C A Forte, B C Knight, D J Betteridge, \\ D A Isenberg
}

\begin{abstract}
Fasting cholesterol, triglyceride, low density lipoprotein cholesterol, high density lipoprotein cholesterol, apoprotein AI, and apoprotein B were measured in 64 patients with systemic lupus erythematosus to assess the risk factors for vascular disease. The relation between the lipid profile, steroid treatment, the presence of anticardiolipin antibodies, and the prevalence of vascular disease was examined. Raised concentrations of triglyceride and apoprotein B were seen in those patients treated with more than the equivalent of $10 \mathrm{mg}$ prednisolone a day in the six months before testing. An increase in vascular disease was found only in the subgroup of patients with increased triglycerides who also expressed anticardiolipin antibodies. This study confirms the association between treatment with high doses of steroids in lupus and the development of an atherogenic plasma lipid profile. The presence of anticardiolipin antibodies compounds the risk of developing vascular disease.
\end{abstract}

Patients with systemic lupus erythematosus have an increased incidence of atherosclerosis, thrombosis, and thromboembolic disease. ${ }^{1-6}$ Some studies have linked this increased incidence of vascular disease in lupus with the expression of antiphospholipid antibodiesnotably, anticardiolipin antibodies. ${ }^{7-10}$

The close correlation between the presence of antiphospholipid antibodies and the lupus anticoagulant suggests that these antibodies may play a direct part in the pathogenesis of vascular disease. ${ }^{11} 12$ Antiphospholipid antibodies act at several sites in the coagulation cascade with an overall effect in vivo of promoting thrombosis. The enhancing effect of phospholipid on the endothelial cell cofactor thrombomodulin is neutralised by antiphospholipid antibodies. As a result, protein $\mathrm{C}$ activation on the surface of endothelial cells is inhibited, promoting thrombosis and suppressing fibrinolysis. ${ }^{13}$ IgG antiphospholipid antibodies interfere with cell surface prostacyclin formation and lead to platelet aggregation. ${ }^{14}$ Direct damage to endothelial cells is also recognised. ${ }^{15}$

Hyperlipidaemia is a recognised risk factor for vascular disease in lupus. ${ }^{16} 17$ The importance of hyperlipidaemia in the pathogenesis of atherosclerosis has been firmly established. ${ }^{18}$ Raised low density lipoprotein cholesterol and its major apoprotein (apoprotein B) are highly atherogenic. Increased concentrations of high density lipoprotein cholesterol and its major apoprotein (AI) afford protection from atherosclerosis. ${ }^{19-21}$ The role of triglyceride as an independent risk factor for atherosclerosis remains uncertain. Certain triglyceride-rich lipoproteins, such as remnant particles, are highly atherogenic. ${ }^{22}$ Ettinger $e t$ al in a study of 46 lupus patients showed low concentrations of high density lipoprotein in patients not treated with steroids. Steroids accentuated this atherogenic lipid profile causing an increase in triglyceride, cholesterol, and low density lipoprotein cholesterol. ${ }^{17}$

Plasma lipids may predispose to vascular disease by mechanisms similar to those postulated for the action of antiphospholipid antibodies. There is an interaction with the clotting cascade, tending to promote thrombosis. ${ }^{23}$ Platelet aggregation is precipitated, ${ }^{24}$ and lipids may directly damage vascular endothelium. ${ }^{25} 26$

This study examines the relation between fasting lipid concentrations, anticardiolipin antibodies, and vascular disease in a group of 64 patients with systemic lupus erythematosus. It examines whether the risk of vascular disease is increased when anticardiolipin antibodies and an abnormal lipid profile occur together.

Patients, materials, and methods PATIENTS

The study group comprised carefully documented patients attending a specialist lupus clinic at the Bloomsbury Rheumatology Unit. All patients fulfilled the revised criteria of the American Rheumatism Association for the classification of SLE. ${ }^{27}$ In 64 sequentially assessed patients fasting cholesterol, triglyceride, low density lipoprotein cholesterol and high density lipoprotein cholesterol were measured. In 46 of these patients apoprotein $\mathrm{AI}$ and apoprotein B were also measured. The control population consisted of 18 healthy controls matched for age and sex.

LIPID ASSAY

Total cholesterol, triglyceride, and high density lipoprotein cholesterol were measured using Boehringer diagnostic kits by an enzymatic colorimetric method. High density lipoprotein cholesterol was obtained after precipitation of very low density lipoprotein cholesterol and low 
density lipoprotein cholesterol by heparin manganous chloride. Low density lipoprotein cholesterol was derived by calculation using the Friedwald equation. ${ }^{28}$ Apolipoprotein $\mathrm{AI}$ and $\mathrm{B}$ were measured by an immunoturbidometric method (Sigma).

\section{ANTICARDIOLIPIN ANTIBODY ASSAY}

Anticardiolipin antibodies were assayed on at least two occasions by an enzyme linked immunosorbent assay in 61 of the lupus patients. $^{29}$

\section{EFFECT OF TREATMENT}

The lupus patients were split into groups according to steroid treatment. Twenty two patients had not received steroids in the six months before testing; 28 patients had been treated with the equivalent of less than 10 $\mathrm{mg} /$ day of prednisolone for the previous six months; 14 had received larger doses. Student's $t$ test was used to compare patient and control groups.

\section{Results}

\section{PLASMA LIPIDS}

The fasting lipid, lipoprotein, and apoprotein values formed a log-normal distribution in patient and control groups (Shapiro Francia W' test). ${ }^{30}$ Table 1 gives the geometric means of the plasma lipid and lipoprotein concentrations. Table 2 shows the mean and $95 \%$ confidence intervals for the mean of the logarithmic distributions. The patient group was divided into three categories according to the average steroid dose in the six months before testing. Significant differences were only noted in patients treated with doses of corticosteroids exceeding $10 \mathrm{mg} /$ day in the six months before testing. In these patients plasma triglyceride and apoprotein B were increased when compared with the control group (Student's $t$ test: $\mathrm{t}=2.989$, degrees of freedom $=30, \mathrm{p}<0.01$ and $\mathrm{t}=4.877$, degrees of freedom $=18, \quad p<0.01$ respectively). Patient age did not influence plasma lipid and lipoprotein concentrations in the lupus patients and there was no relation between the expression of anticardiolipin antibodies and fasting lipid and lipoprotein concentrations. Figures 1 and 2 show the frequency distribution of triglyceride and apoprotein B in the patient and control groups and illustrate the relation with steroid treatment.

\section{PREVALENCE OF VASCULAR DISEASE}

A clearly documented history of a major vascular episode was present in 13 of the 64

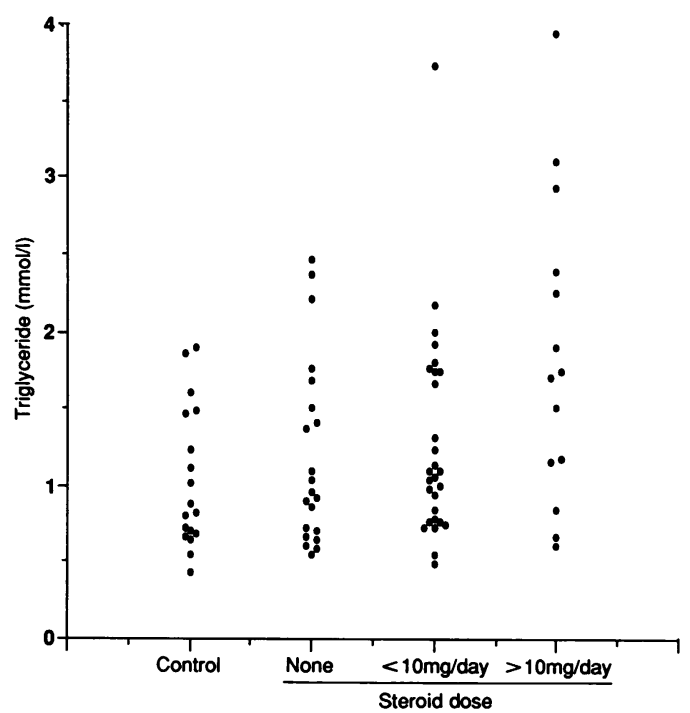

Figure 1 Triglyceride concentrations in patients with systemic lupus erythematosus and in controls. The groups are divided according to steroid treatment.

Table 1 Geometric mean of lipid and apoprotein concentrations of the group with systemic lupus erythematosus (SLE) and of the control group

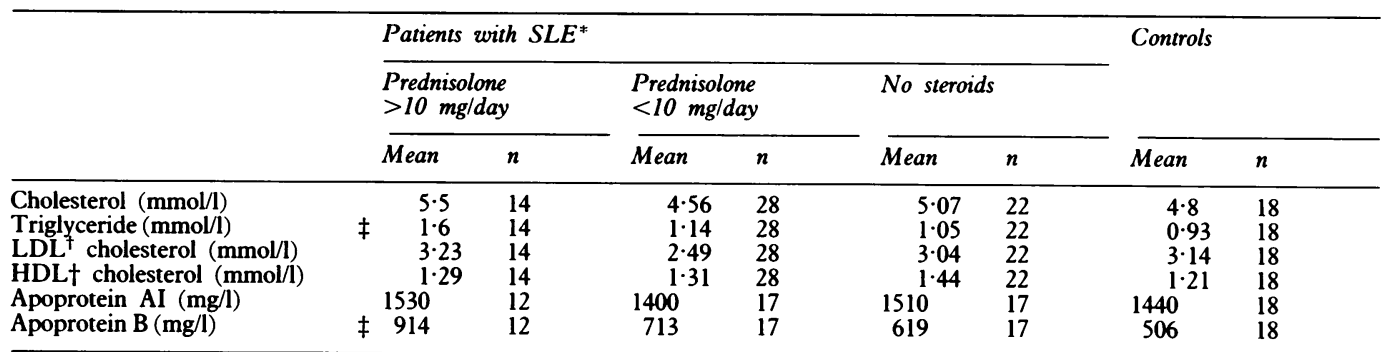

*The group with SLE were divided according to the steroid treatment received in the previous six months.

$+\mathrm{LDL}=$ low density lipoprotein; $\mathrm{HDL}=$ high density lipoprotein. $\ddagger$ Denotes significant difference from control group (Student's $t$ test: $p<0 \cdot 01$ ) based on analysis using log-transformed data (details
in table 2).

Table 2 Mean of the logarithm (base 10) of the lipid and apoprotein concentrations of the group with systemic lupus erythematosus (SLE) and of the control group. The $95 \%$ confidence interval is shown in parentheses

\begin{tabular}{|c|c|c|c|c|c|c|c|c|c|c|c|}
\hline & & \multicolumn{8}{|c|}{ Patients with $S L E^{*}$} & \multirow{2}{*}{\multicolumn{2}{|c|}{ Controls }} \\
\hline & & \multicolumn{4}{|c|}{ Prednisolone $>10 \mathrm{mg} /$ day } & \multicolumn{2}{|c|}{ Prednisolone $<10 \mathrm{mg} /$ day } & \multicolumn{2}{|c|}{ No steroids } & & \\
\hline & & Mean & $(C I)$ & & $n$ & Mean & $(C I)$ & Mean & $(C I)$ & Mean $\quad(C I)$ & $n$ \\
\hline $\begin{array}{l}\text { Cholesterol } \\
\text { Triglyceride } \\
\text { LDL† cholesterol }(\mathrm{mmol} / \mathrm{l}) \\
\text { HDLt cholesterol }(\mathrm{mmol} / \mathrm{l}) \\
\text { Apoprotein AI (mg/l) } \\
\text { Apoprotein B (mg/l) }\end{array}$ & $\ddagger$ & $\begin{array}{l}0 \cdot 740 \\
0 \cdot 205 \\
0 \cdot 509 \\
0 \cdot 109 \\
3 \cdot 165 \\
2 \cdot 961\end{array}$ & $\begin{array}{l}(0.686 \text { to } \\
(0.088 \text { to } \\
(0.429 \text { to } \\
(0.018 \text { to } \\
(3.089 \text { to } \\
(2.882 \text { to }\end{array}$ & $\begin{array}{l}0 \cdot 794) \\
0 \cdot 322) \\
0 \cdot 589) \\
0 \cdot 200) \\
3 \cdot 241) \\
3 \cdot 040)\end{array}$ & $\begin{array}{l}14 \\
14 \\
14 \\
14 \\
12 \\
12\end{array}$ & $\begin{array}{l}0.659 \\
0.056 \\
0.396 \\
0 \cdot 116 \\
3 \cdot 147 \\
2.853\end{array}$ & $\begin{array}{l}(0.605 \text { to } 0 \cdot 702) 28 \\
(-0.021 \text { to } 0 \cdot 132) 28 \\
(0.325 \text { to } 0 \cdot 467) 28 \\
(0.078 \text { to } 0 \cdot 154) 28 \\
(3.112 \text { to } 3 \cdot 1781) 17 \\
(2 \cdot 750 \text { to } 2 \cdot 956) 17\end{array}$ & $\begin{array}{l}0 \cdot 705 \\
0 \cdot 021 \\
0 \cdot 483 \\
0 \cdot 159 \\
3 \cdot 181 \\
2 \cdot 792\end{array}$ & $\begin{array}{l}(0.688 \text { to } 0.722) 22 \\
(-0.065 \text { to } 0 \cdot 107) 22 \\
(0.430 \text { to } 0.536) 22 \\
(0.112 \text { to } 0 \cdot 206) 22 \\
(3.132 \text { to } 3.230) 17 \\
(2.698 \text { to } 2 \cdot 886) 17\end{array}$ & $\begin{array}{c}0.681(0.636 \text { to } 0 \cdot 726) \\
-0 \cdot 027(-0 \cdot 115 \text { to } 0.061) \\
0 \cdot 479(0 \cdot 410 \text { to } 0 \cdot 548) \\
0 \cdot 086(0 \cdot 037 \text { to } 0 \cdot 135) \\
3 \cdot 159(3.106 \text { to } 3 \cdot 212) \\
2 \cdot 704(2.638 \text { to } 2 \cdot 770)\end{array}$ & $\begin{array}{l}18 \\
18 \\
18 \\
18 \\
18 \\
18\end{array}$ \\
\hline
\end{tabular}

The group with SLE were divided according to the steroid treatment received in the previous six months.

$\dagger \mathrm{LDL}=$ low density lipoprotein; $\mathrm{HDL}=$ high density lipoprotein

$\ddagger$ Denotes significant difference from control group (Student's $t$ test: $p<0.01$ ). 


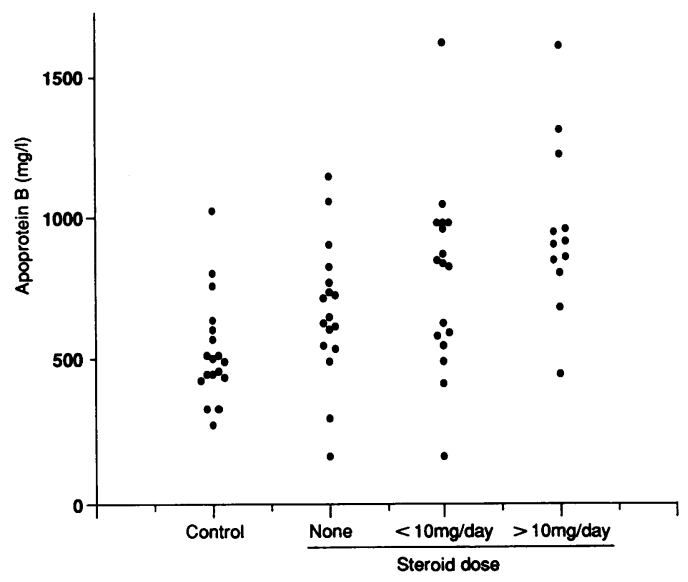

Figure 2 Apoprotein $B$ concentrations in patients with systemic lupus erythematosus and in controls. The groups are divided according to steroid treatment.

Table 3 Information on the 13 patients with systemic lupus erythematosus with a history of major vascular episodes in whom lipid concentrations and anticardiolipin antibodies were assayed

\begin{tabular}{|c|c|c|c|c|}
\hline Age & Anticardiolipin & Immunoglobulin class & Steroid dose & Vascular history \\
\hline 41 & Positive & G, $M$ & A & $\begin{array}{l}\text { Miscarriage } \\
\text { Cerebral embolus }\end{array}$ \\
\hline $\begin{array}{l}40 \\
28 \\
31 \\
60\end{array}$ & $\begin{array}{l}\text { Positive } \\
\text { Positive } \\
\text { Positive } \\
\text { Positive }\end{array}$ & $\begin{array}{l}\text { G, } \\
\text { G, } \\
\text { M } \\
\text { G }\end{array}$ & $\begin{array}{l}\text { B } \\
\text { C } \\
\text { B } \\
\text { C }\end{array}$ & $\begin{array}{l}\text { Deep vein thrombosis } \\
\text { Deep vein thrombosis } \\
\text { Cerebral arterial thrombosis } \\
\text { Pulmonary embolus } \\
\text { Angina } \\
\text { Deep vein thrombosis }\end{array}$ \\
\hline $\begin{array}{l}54 \\
35 \\
44\end{array}$ & $\begin{array}{l}\text { Positive } \\
\text { Positive } \\
\text { Positive }\end{array}$ & $\begin{array}{l}\text { G } \\
\text { G } \\
\text { }\end{array}$ & $\begin{array}{l}\text { B } \\
\text { B } \\
\text { A }\end{array}$ & $\begin{array}{l}\text { Brachial artery thrombosis } \\
\text { Cerebral arterial thrombosis } \\
\text { Transient ischaemic attack } \\
\text { Deep vein thrombosis }\end{array}$ \\
\hline $\begin{array}{l}60 \\
67 \\
45\end{array}$ & $\begin{array}{l}\text { Negative } \\
\text { Negative } \\
\text { Negative }\end{array}$ & & $\begin{array}{l}\text { B } \\
\text { B } \\
\text { C }\end{array}$ & $\begin{array}{l}\text { Deep vein thrombosis } \\
\text { Deep vein thrombosis } \\
\text { Small bowel infarct } \\
\text { Transient ischaemic attack } \\
\text { Deep vein thrombosis }\end{array}$ \\
\hline 46 & Negative & & $\mathrm{C}$ & $\begin{array}{l}\text { Transient ischaemic attack } \\
\text { Deep vein thrombosis }\end{array}$ \\
\hline 28 & Negative & & A & Pulmonary embolism \\
\hline
\end{tabular}

${ }^{*} \mathrm{~A}=$ no steroid; $\mathrm{B}=<10 \mathrm{mg}$ prednisolone/day; $\mathrm{C}>10 \mathrm{mg}$ prednisolone/day.

patients. Table 3 lists these episodes, including arterial and venous thrombotic and thromboembolic disorders. The average age of the patients with vascular disease was 44.5 years compared with $39 \cdot 2$ in the unaffected lupus patients. This difference was not statistically significant. Ten of the 13 patients with vascular disease had been treated with steroids, four at doses greater than $10 \mathrm{mg} /$ day for six months before testing, suggesting that the disease had been more active than in those without a history of vascular complications.

\section{CORRELATIONS WITH VASCULAR DISEASE}

Raised anticardiolipin antibodies were detected in eight of the 13 patients with vascular disease. One expressed IgM alone, three expressed both IgG and IgM, and four expressed IgG alone. Of the 48 remaining patients with no vascular disease in whom anticardiolipin antibodies were assayed, detectable antibody levels were found in 14. The higher prevalence of anticardiolipin antibodies among the patients with vascular disease was not statistically significant at the $\mathrm{p}<0.05$ level.

No significant difference was noted in fasting lipid and apoprotein concentrations when patients with and without vascular complications were compared.

Of the patients in the upper third of the

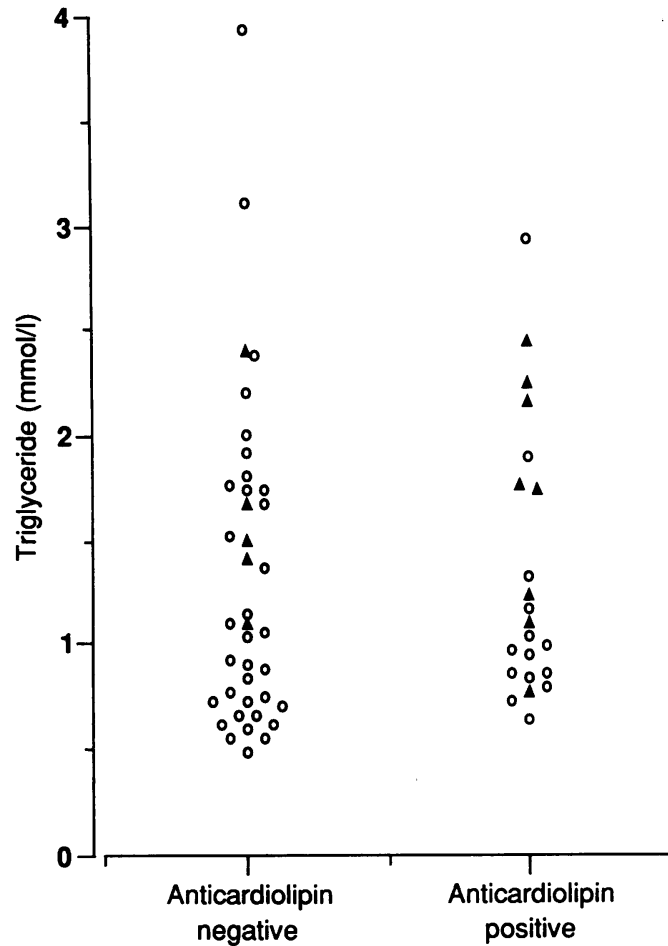

Figure 3 Triglyceride concentrations in 61 patients with systemic lupus erythematosus illustrating the higher prevalence of vascular disease in those patients with high triglyceride concentrations who were also anticardiolipin positive. $(\Delta)$ represent patients with a history of vascular disease.

triglyceride range (20 out of 61 patients), seven were anticardiolipin antibody positive. Five of these seven patients had had a major vascular event. This compares with only eight patients who had had vascular events in the remaining 54 patients studied. The higher prevalence of vascular disease in this subgroup of anticardiolipin positive patients with high triglyceride concentrations is significant $\left(\chi^{2}\right.$ (with Yates's correction) $=8 \cdot 71$, degree of freedom $=1$, $\mathrm{p}<0 \cdot 01)$. Figure 3 illustrates this increased prevalence.

\section{Discussion}

Vascular complications contribute significantly to the morbidity and mortality of systemic lupus erythematosus. ${ }^{6}$ In this study the previous observation of an atherogenic plasma lipid profile in lupus patients was confirmed. ${ }^{17}$ Increased concentrations of triglyceride and apoprotein B were noted in patients who had been treated with doses of corticosteroids exceeding the equivalent of $10 \mathrm{mg} /$ day of prednisolone in the six months before testing. We were unable to detect lipid abnormalities in the lupus patients who had received no recent steroid treatment. In particular, the low concentrations of high density lipoprotein cholesterol that have been detected previously in untreated lupus patients were not found. The presence of normal concentrations of cholesterol and low density lipoprotein cholesterol in the group in whom apoprotein $B$ was raised suggests that these patients may have abnormally dense particles of low density lipoprotein.

Vascular disease was a common complication in the group studied. We were unable to show a 
direct relation between lipid concentrations and the prevalence of major vascular episodes. This is not surprising given the relatively small size of the group studied. Restricted patient numbers may also account for the lack of significant correlation between the expression of anticardiolipin antibodies and vascular disease. Previous studies have reported discordant results about this possible link. Some studies have described a strong positive association between anticardiolipin antibodies and thrombotic events. ${ }^{31}$ Others have not confirmed this. ${ }^{32}$ In this study vascular events were particularly common in those patients who had both an increased triglyceride concentration and who expressed anticardiolipin antibodies. This suggests that the two abnormalities compound the risk of vascular disease.

Multiple factors are likely to influence the risk of developing vascular complications in lupus. This study confirms the importance of anticardiolipin antibodies and steroid induced abnormalities in the fasting lipid profile in contributing to the pathogenesis of vascular disease in these patients. Possibly these two risk factors may be more intimately linked by similar participation in the mechanism of coagulation.

1 Bonfiglio T A, Botti R E, Hagstrom J W. Coronary arteritis, occlusion and myocardial infarction due to lupus erythematosus. Am Heart f 1972; 83: 153-8.

2 Homcy C J, Liberthson R R, Fallon J T, Gross S, Mille $L M$. Ischaemic heart disease in SLE in young patients; report of six cases. Am $\mathcal{F}$ Cardiol 1982; 49: 478-84.

3 Spiera H, Rothenburg R. Myocardial infarction in four young Spiera H, Rothenburg R. Myocardial infarction in fou

4 Jensen G, Sigurd B. SLE and acute myocardial infarction. Chest 1973; 64: 653-4.

5 Haider Y S, Roberts W C. Coronary arterial disease in SLE: quantification of degree of narrowing in 22 necropsy patients (21 women) aged 16 to 37 years. $A m \mathcal{F}$ Med 1981 ; 70: $775-81$

6 Rubin L A, Urowitz M B, Gladman D D. Mortality in SLE, the bimodal pattern revisited. Q F Med 1985; 55: 87-98.

7 Harris E N, Gharavi A E, Boey M L, et al. Anticardiolipin antibodies: detection by radioimmunoassay and association with thrombosis in systemic lupus erythematosus. Lancet 1983; ii: $1211-4$.

8 Harris E N, Gharavi A E, Asherson R A, Boey M L, Hughes G R V. Cerebral infarction in systemic lupus associated w $R$ V. Cerebral infarction in systemic lupus associated with anticis 4 .

9 Hamsten A, Norberg R, Bjornholm M, de Faire U, Holm G. Antibodies to cardiolipin in young survivors of myocardial infarction: an association with recurrent cardiovascular events. Lancet 1986; i: 113-6.
10 Asherson R A, Derkson R H, Harris E N, et al. Large vessel occlusion and gangrene in systemic lupus erythematosus and "lupus-like" disease: a report of six cases. $\mathcal{F}$ Rheumatol 1986; 13: 740-7.

11 Pengo V, Thalgarian P, Shapiro S S, Heine M J. Immunological specificity and mechanisms of action of IgG lupus logical specificity and mechanisms of

12 Alarcon-Segovia D. Pathogenic potential of antiphospholipid antibodies. $\mathcal{F}$ Rheumatol 1988; 15: 890-3.

13 Freysinnet J M, Gauchy J, Cazenave J P. The effect of phospholipids on the activation of protein $\mathbf{C}$ by the human phospholipids on the activation of protein $C$ by the human
thrombin-thrombomodulin complex. Biochem $\mathcal{F}$ 1986; 238: thrombin-7.

14 Byron M A, Allington M J, Chapel H M, Mowat A G Cederholm-Williams S A. Indications of vascular endothelial dysfunction in SLE. Ann Rheum Dis 1987; 46: 741-5.

15 Vismara A, Meroni P L, Tincani A, et al. Relationship between anticardiolipin antibodies and antiendothelial cell antibodies in SLE. Clin Exp Immunol 1988; 74: 247-53.

16 Buckley B H, Roberts W C. The heart in SLE and the changes induced in it by corticosteroid therapy. $A m \mathcal{F ~ M e d}$ 1975; 58: $243-64$.

17 Ettinger W H, Goldberg A P, Applebaum-Bowden D Hazzard $W$ R. Dyslipoproteinaemia in SLE. Effects of Hazzard W R. Dyslipoproteinaemia in SLE.

18 Inkeles S, Eisenberg D. Hyperlipidaemia and coronary atherosclerosis: a review. Medicine (Baltimore) 1981; 60: $110-23$

19 Vergani C, Trovato G, Dioguardi N. Serum total lipids and lipoproteins, cholesterol, apoprotein $\mathrm{A}$ and $\mathrm{B}$ in cardiovascular disease. Clin Chim Acta 1978; 87: 127-33.

20 Noma A, Yokosuka T, Kitamura K. Plasma lipids and apoproteins as discriminators for the presence and severity of angiographically defined coronary artery disease. Atherosclerosis 1983; 49: 1-7.

21 Avogaro P, Pittio B G, Cazalotto G. Are apolipoproteins better discriminators than lipids for atherosclerosis? Lancet 1979; i: 901-3.

22 Zilversmit D B. Atherogenesis: a post prandial phenomenon. Circulation 1979; 60: 473-85.

23 Bruckdorfer K R. Lipids and thrombosis. F R Soc Med 1988; 81: 299-305.

24 Lupu C, Calb M. Changes in the platelet surface charge in rabbits with experimental hypercholesterolaemia. Atherosclerosis 1988; 72: 77-82.

25 Cathcart M K, Morel D W, Chisolm G M. Monocytes and neutrophils oxidise low density lipoprotein making it cytotoxic. F Leukoc Biol 1985; 38: 341-50.

26 Jackson R A, Gotto A M. Hypothesis concerning membrane structure, cholesterol and atherosclerosis. In: Paoletti $R$, Gotto A M, eds. Atherosclerosis Reviews. Vol 1. New Yotto A Maven Press, 1986: 1-21.

27 Tan E M, Cohen A S, Fries J F, et al. Revised ARA criteria for SLE. Arthritis Rheum 1982; 25: 1271-7.

28 Friedwald W T, Levy R I, Fredrickson D S. Estimation of the concentration of low density lipoprotein cholesterol without use of the preparative ultracentrifuge. Clin Chem 1972; 18: 499-502.

29 Isenberg D A, Williams W, Le Page S, et al. A comparison of autoantibodies and common DNA antibody idiotypes in SLE patients and their spouses. $B r \mathcal{F}$ Rheumatol 1988; 27 : 431-6.

30 Royston J P. A simple method for evaluating the Shapiro Francia W' test of non-normality. The Statistician 1983; 32 297-300.

31 Mackworth-Young C G, Louisou S, Walport M J. Antiphospholipid antibodies and disease. $Q \mathcal{F}$ Med 1989; 72 . 767-77.

32 Sturfelt G, Nived O, Norberg R, Thortennson R, Krook K. Anticardiolipin antibodies in patients with SLE. Arthritis Rheum 1987; 30: 382-8. 